\title{
Seedling Morphology of (Euterpe precatoria MART.) under Levels of Irradiance
}

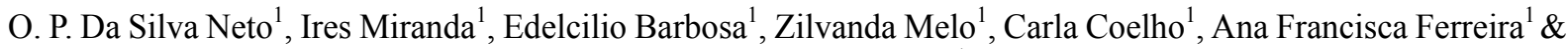 \\ Thiago Andrade Miranda ${ }^{1}$ \\ ${ }^{1}$ Research Group Amazonian palm trees, Biodiversity Coordination, National Institute for Amazonian Research in \\ Manaus, Brazil \\ Correspondence: O. P. Da Silva Neto, Research Group Amazonian palm trees, Biodiversity Coordination, \\ National Institute for Amazonian Research in Manaus, Brazil. E-mail: excellentmind2009@yahoo.com
}

Received: June 13, 2015 Accepted: July 13, 2015 Online Published: September 15, 2015

doi:10.5539/jas.v7n10p198 URL: http://dx.doi.org/10.5539/jas.v7n10p198

\begin{abstract}
The Euterpe precatoria Mart. palm. (Acai-do-Amazonas) has been investigated with the aim of sustainability. The palm that is mainly used for basic nutrition of local populations, could also form the basis for models of self-sustained technological and industrial development. The extractive exploitation mainly in riverside communities, where its use is essential in food, it presents insufficient to attend a business model in isolated communities. Therefore, the study was based on obtaining knowledge and its potential applicability in the production of seedling, by increasing levels of irradiance in order to evaluate its growth in diameter, height and number of leaves. In the analysis of growth in different irradiation levels E. precatoria Mart. showed no significant difference in height, the diameter had high development in seedlings subjected to higher levels of irradiance and the number of leaves was higher in the environment with lower irradiance index. The behavior exhibited by the species suggests that $E$. precatoria tolerates environments with different levels of irradiance.
\end{abstract}

Keywords: Amazon, growth, monocot, shade, substrate, tropical

\section{Introduction}

Euterpe precatoria Mart. is distributed throughout the Amazon region (Miranda et al., 2001), one of the most widespread and common species of the family and gender, in the Neotropics (Henderson, 1995). This species are spread by seed, by the fact that it has no tillers, as Euterpe oleracea. The germination is generally characterized by difficulties, which vary from the morphological characteristics of the seeds to the physiological peculiarities of the germination process, hindering the production and subsequent establishment of the seedlings (Cunha \& Garden, 1995).

That research, relating to growth of seedling, showed that the seed are very important in commercial practice, as the palm trees, mostly, are propagated through the seeds, especially those who do not have tillers. Miranda et al. (2008) argue that descriptive studies of palm trees seed germination are important to the full knowledge of the germ and basic process for efficient technical development of seedling production. Regarding this aspect, we highlight the work of Jordan (1970), Pinheiro Neto and Araújo (1985), Queiroz (1986), and Belin and Queiroz (1987).

The installation of sustainable plantations of E. precatoria under natural conditions require more studies related to large-scale adaptability of planting, as studies related to monitoring germination and seedlings. Most likely, this would provide greater possibility of perpetuation of the species, favoring the establishment of progeny. Thus, this study aims to evaluate the performance germination and early growth of seedlings (Miranda, Barbosa, Rabelo, \& Santiago, 2008).

\section{Materials and Methods}

\subsection{Location of Study}

The study was conducted at the Laboratory of Palms - LabPalm, Biodiversity Coordination (CBIO) of the National Institute of Amazonian Research (MCTI - INPA), located in Manaus, AM, Brazil. 


\subsection{Experimental Installation for Monitoring the Seedlings}

Seedlings of Euterpe precatoria were selected in the nursery of the Laboratory of studies in Palms, INPA (LABPALM), for uniformity of size and plant sanity. The experiment was mounted in suspended benches and the experimental design was completely randomized in 4 treatments with 7 repeats (seedlings):

$\mathrm{T} 1=30 \%$ (200 to $400 \mu \mathrm{mol}$ photons $\left.\mathrm{m}^{-2} \mathrm{~s}^{-1}\right)$;

$\mathrm{T} 2=50 \%$ (500 to $700 \mu \mathrm{mol}$ photons $\left.\mathrm{m}^{-2} \mathrm{~s}^{-1}\right)$;

$\mathrm{T} 3=70 \%$ irradiance $\left(8001000 \mu \mathrm{mol}\right.$ photons $\left.\mathrm{m}^{-2} \mathrm{~s}^{-1}\right)$;

$\mathrm{T} 4=$ full sun $\left(1300-1800 \mu \mathrm{mol}\right.$ photons $\left.\mathrm{m}^{-2} \mathrm{~s}^{-1}\right)$.

It is noteworthy that the bands of light may vary depending on the time of year. The plants studied were packed in polyethylene bags (initially $500 \mathrm{~g}$, later $2 \mathrm{~kg}$ and $5 \mathrm{~kg}$ ) containing black earth and vermiculite.

\subsection{Parameters Assessed}

The analysis parameters were taken every 15 days during a period of 8 months. The following quantitative and qualitative parameters were: height $(\mathrm{cm})$, diameter $(\mathrm{mm})$, number of leaves, sanity (for viewing), mortality and survival of seedlings.

\subsection{Survival and/or Mortality}

The survival was calculated by the formula:

$$
S(\%)=((N-n) / N) \times 100
$$

Used by (Moreira, 2011), where:

S (\%) Survival rate species; N: Number of individuals of the species planted; n: number of dead plants of the species.

\subsection{Statistical Analysis}

The results were submitted to analysis of variance and means were compared with each other by $5 \%$ Tukey test, considering the normality we used the Kruskal Wallis test in the analyse of diameter (Zar, 1974) using the Program ASSISTAT - Assistance Statistics (version 7.7 Beta) UFCG - Campina Grande-PB (Silva \& Azevedo, 2009).

\section{Results and Discussion}

The plant growth is dependent change in the physiology which can be assimilated by the measurement rate and/or the morphology of the plant (Hunt, 1982). In this work we were studied morphological parameters, measured the diameter, height and number of leaves.

As for the time there were no significant differences between treatments (Table 1). Meirelles (2007) evaluated the increase in palm-raffia height under different shading screens and concluded that there was no difference in the development of seedlings; this result supports the results of this work. 
Table 1. Height of palm açai seedlings (Euterpe precatoria Mart., Arecaceae) in 4 treatments

\begin{tabular}{llllll}
\hline \multicolumn{5}{c}{ Irradiance } \\
\hline Time (days) & $\mathbf{3 0 \%}$ & $\mathbf{5 0 \%}$ & $\mathbf{7 0 \%}$ & Full sunlight & F \\
\hline $\mathbf{1 5}$ & 15,88571 & 15,20000 & 14,35714 & 14,88571 & $1.6501^{\text {ns }}$ \\
$\mathbf{3 0}$ & 16,47143 & 15,91429 & 14,54286 & 15,44286 & $2.2557^{\mathrm{ns}}$ \\
$\mathbf{4 5}$ & 16,94286 & 16,55714 & 14,54286 & 15,97143 & $0.8246^{\mathrm{ns}}$ \\
$\mathbf{6 0}$ & 17,40000 & 16,87143 & 17,17143 & 16,72857 & $0.2075^{\mathrm{ns}}$ \\
$\mathbf{7 5}$ & 18,31429 & 17,40000 & 18,07143 & 19,42857 & $1.7530^{\mathrm{ns}}$ \\
$\mathbf{9 0}$ & 19,40000 & 18,21428 & 17,97143 & 20,34286 & $2.4376^{\mathrm{ns}}$ \\
$\mathbf{1 0 5}$ & 20,42857 & 19,17143 & 19,54286 & 21,20000 & $1.8451^{\mathrm{ns}}$ \\
$\mathbf{1 2 0}$ & 20,85714 & 20,38571 & 20,11429 & 21,54286 & $0.9272^{\mathrm{ns}}$ \\
$\mathbf{1 3 5}$ & 21,38571 & 20,82857 & 20,90000 & 22,01429 & $0.6254^{\mathrm{ns}}$ \\
$\mathbf{1 5 0}$ & 21,95714 & 21,05714 & 21,21428 & 22,74286 & $1.0025^{\mathrm{ns}}$ \\
$\mathbf{1 6 5}$ & 22,15714 & 21,21428 & 22,37143 & 23,91429 & $1.4409^{\mathrm{ns}}$ \\
$\mathbf{1 8 0}$ & 22,62857 & 21,30000 & 22,75714 & 24,38571 & $1.6120^{\text {ns }}$ \\
$\mathbf{1 9 5}$ & 23,24286 & 21,97143 & 23,10000 & 24,81429 & $1.4873^{\mathrm{ns}}$ \\
$\mathbf{2 1 0}$ & 23,88571 & 22,27143 & 23,64286 & 25,01429 & $1.4388^{\mathrm{ns}}$ \\
$\mathbf{2 2 5}$ & 24,84286 & 22,91429 & 24,24286 & 25,50000 & $1.1710^{\mathrm{ns}}$ \\
\hline
\end{tabular}

Note. Critical F: 3.0088; CV <30; ns: no significant differences $(\mathrm{p}<0.05)$.

Regarding the number of leaves, significant differences with higher averages were observed in shaded treatments not continuous analysis (Table 2). The plants were at higher irradiance greater variation in reduced number of plant leaves in shading conditions, meaning that this condition was greater falling leaves resulting in an increase in diameter.

Table 2. Number of açaí palm leaves (Euterpe precatória Mart., Arecaceae) in 4 treatments

\begin{tabular}{llllll}
\hline \multicolumn{5}{c}{ Irradiance } \\
\hline Time (days) & $\mathbf{3 0 \%}$ & $\mathbf{5 0 \%}$ & $\mathbf{7 0 \%}$ & Full Sunlight & F \\
\hline $\mathbf{1 5}$ & 3,42857 & 3,71429 & 3,85714 & 3,57143 & 2,7000 \\
$\mathbf{3 0}$ & 3,57143 & 3,85714 & 4,00000 & 3,85714 & 2,4184 \\
$\mathbf{4 5}$ & 3,57143 & 3,85714 & 4,00000 & 3,85714 & 2,4184 \\
$\mathbf{6 0}$ & 3,71429 & 4,14286 & 4,00000 & 3,85714 & 1,5577 \\
$\mathbf{7 5}$ & 3,71429 & 4,57143 & 4,57143 & 4,42857 & 6,0239 \\
$\mathbf{9 0}$ & 4,00000 & 4,57143 & 4,57143 & 4,42857 & 3,9284 \\
$\mathbf{1 0 5}$ & $4.14286^{\circ}$ & $4.71429 a$ & $5.00000 a$ & $4.85714 a$ & $8,8094^{*}$ \\
$\mathbf{1 2 0}$ & $4.14286^{\circ}$ & $4.71429 a$ & $5.00000 a$ & $4.85714 a$ & $8,8094^{*}$ \\
$\mathbf{1 3 5}$ & 4,57143 & 4,71429 & 5,14286 & 4,85714 & 4,5604 \\
$\mathbf{1 5 0}$ & 4,71429 & 4,71429 & 4,85714 & 4,71429 & 0,5238 \\
$\mathbf{1 6 5}$ & 4,85714 & 4,85714 & 5,14286 & 4,57143 & 3,3884 \\
$\mathbf{1 8 0}$ & 5,00000 & 4,85714 & 5,14286 & 4,71429 & 2,1039 \\
$\mathbf{1 9 5}$ & $5.14286^{\circ}$ & $4.85714 a b$ & $5.00000 a b$ & $4.28571 b$ & 7,7193 \\
$\mathbf{2 1 0}$ & $5.28571^{\circ}$ & $4.85714 a b$ & $5.14286 a b$ & $4.57143 b$ & $8,2047^{*}$ \\
$\mathbf{2 2 5}$ & 5,14286 & 5,00000 & 4,71429 & 4,57143 & 4,3068 \\
\hline
\end{tabular}

Note. Critical H: 7,8147; ns: no significant diferences $(p<0.05)$.

Significant differences were found in diameter at 210 days by $\mathrm{F}$ test, however the difference was not sensitive to the Tukey test. This case is provided in the literature, F can approach but not reach significance and yet the Tukey 
test can find significant difference between the highest and the lowest average or the reverse may also occur also occurs with other comparison tests It should not be understood as an error in the analysis (XX ASSISTAT). To 225 days, plants under full sunlight showed statistically on average diameters greater than those shaded by Tukey test $(\mathrm{P}>0.05)$ (Table 3).

Table 3. Diameter of palm açaí seedlings (Euterpe precatoria Mart., Arecaceae) under different levels of irrandiance

\begin{tabular}{llllll}
\hline \multicolumn{5}{c}{ Irradiance } \\
\hline Time (days) & $\mathbf{3 0 \%}$ & $\mathbf{5 0 \%}$ & $\mathbf{7 0 \%}$ & Full Sunlight & F \\
\hline $\mathbf{1 5}$ & 7,26286 & 7,28286 & 6,81857 & 7,03571 & $1.2485^{n s}$ \\
$\mathbf{3 0}$ & 7,42143 & 7,51714 & 7,14429 & 7,24286 & $0.7007^{n s}$ \\
$\mathbf{4 5}$ & 7,54000 & 7,87143 & 7,83286 & 7,51571 & $0.8681^{n s}$ \\
$\mathbf{6 0}$ & 7,88429 & 8,11571 & 8,26429 & 8,15429 & $0.4850^{n s}$ \\
$\mathbf{7 5}$ & 8,27429 & 8,38000 & 8,51143 & 8,77143 & $0.5802^{n s}$ \\
$\mathbf{9 0}$ & 8,45571 & 8,80857 & 9,01714 & 8,99143 & $0.8183^{n s}$ \\
$\mathbf{1 0 5}$ & 8,59857 & 9,24286 & 9,61000 & 9,20429 & $1.8157^{n s}$ \\
$\mathbf{1 2 0}$ & 8,84429 & 9,38143 & 9,84572 & 9,46286 & $1.6289^{n s}$ \\
$\mathbf{1 3 5}$ & 9,09714 & 9,48571 & 10,19714 & 9,75143 & $2.2177^{n s}$ \\
$\mathbf{1 5 0}$ & 9,24571 & 9,61857 & 10,44714 & 10,17571 & $2.8777^{n s}$ \\
$\mathbf{1 6 5}$ & 9,78000 & 9,76429 & 10,76143 & 10,54143 & $2.7591^{n s}$ \\
$\mathbf{1 8 0}$ & 9,88143 & 9,98429 & 10,81571 & 10,96714 & $2.6020^{n s}$ \\
$\mathbf{1 9 5}$ & 10,12857 & 10,15286 & 11,07286 & 11,24000 & $2.6020^{n s}$ \\
$\mathbf{2 1 0}$ & 10,13429 & 10,39286 & 11,16571 & 11,49857 & $3.3246^{*}$ \\
$\mathbf{2 2 5}$ & $10.33571 b$ & $10.61000 a b$ & $11.32429 a b$ & $11.85286 a$ & $3.4215^{*}$ \\
\hline
\end{tabular}

Note. Critical F: 3.0088; CV < 30; ns: no significant difference $(p<0.05)$; *: significant at 5\% probability $(p<$ $0.05)$.

A similar result was completed by Claussen (1996), Euterpe edulis palm seedlings subjected to environments with more light had higher development. According to Coelho, Miranda, Melo, and Barbosa (2015), Euterpe precatoria seedlings showed increase in their photosynthetic apparatus to the largest accumulation of chlorophyll b in order to maximize light gathering for acclimatization in shaded environments. Plants submitted the conditions of higher irradiance needed not this amendment to the maintenance of their metabolism, possibly it could invest more energy in development, expressed a greater diameter than the others.

The occurrence of mortality was not found meaning 100\% survival of seedlings.

\section{Conclusion}

Through the results of this work can be inferred that the species E. precatoria are tolerance to environments with different irradiance levels, however presented a better developing diameter plants that are in full sun, perhaps it can be due not invest in a compensatory effect for obtaining necessary light. The time required for this response to occur with greater diameter growth by plants in full sunlight was 210 days. This behavior is a favorable feature for the production of sustainable seedlings for purposes of use in the production chain of açai.

\section{References}

Belin, M., \& Queiroz, M. H. (1987). Contribution to the ontogenetic study of palm trees. Some aspects of germination of Euterpe edulis Mart (pp. 211-213). In Enc. Nac. de Pesq. de Palmito, I. Curitiba, EMBRAPA-CNPq.

Claussen, J. W. (1996). Acclimation abilities of three tropical rainforest seedlings to an increase in light intensity. Forest Ecology and Management, 80, 245-255. http://dx.doi.org/10.1016/0378-1127(95)03599-7

Coelho,C. F., Miranda, I. P. A., Melo, Z. L. O., \& Barbosa, E. M. (2015). Physiological Behave of Acai Seedlings (Euterpe precatoria MART.) under Increasing Levels of Irradiance. J. of Agri. Sci., 7(3), 236-242. http://dx.doi.org/10.5539/jas.v7n3p236 
Cunha, A. C. C., \& Jardim, M. A. G. (1995). I Boletim do Museu Paraense Emílio Goeldi. Série Botânica, 11(1), 55-60. http://dx.doi.org/10.1590/S0100-29452006000300030

Henderson, A. (1995). The palms of the Amazon (p. 362). Oxford: University Press.

Hunt, R. (1982). Plant growth curves: The functional approach to plant growth analysis. Edward Arnold Publishers, London.

Jordan, C. B. (1970). A study of germination and use in twelve palms of northeastern Peru. Principes, 14(1), 26-32.

Meirelles, A. J. A., Paiva, P. D. O., Oliveira, M. I., \& Tavares, T. S. (2007). Influence of different shades and foliar nutrition in the development of raffia palm seedlings Rhapis excelsa (Thunberg) Henry ex. Rehder. Ciênc. Agrotec., Lavras, 31(6), 1884-1887. http://dx.doi.org/10.1590/S1413-70542007000600043

Miranda, I. P. A., Rabelo, A., Bueno, C. R., Barbosa, E. M., \& Ribeiro, M. N. S. (2001). Amazon palm fruit (p. 120). MCT/INPA. Manaus.

Miranda, I. P. A., Barbosa, E. M., Rabelo, A., \& Santiago, F. F. (2008). Palm tres from riparian communities as a sustainable resource in the Brasilian Amazon.

Moreira, F. L. (2011). Initial growth of native and exotic tree species in Jeronimo Monteiro-ES (p. 43). UFES. Monograph end of the course.

Pinheiro, C. U. B., \& Araújo Neto, A. (1985). Germination of the complex babassu palm seeds (Palmae cocosoideae) (Vol. 13, p. 4). São Luís: EMAPA-Pesquisa em andamento.

Queiroz, M. H. (1986). Germinal button palmiteiro as germination indicator. Revista Brasileira de Sementes, 2, 55-59. http://dx.doi.org/10.17801/0101-3122/rbs.v8n2p55-59

Silva, F. de A. S. E., \& Azevedo, C. A. V. de. (2009) Principal Components Analysis in the Softwar Assistat-tatistical Attendance. In World Congress on Computers in Agriculture, 7 Reno-NV-USA: American Society of Agricultural and Biological Engineers, 2009.

Zar, J. H. (1974). Bioestatistical analysis. Preice-Hall International, Inc. London.

\section{Copyrights}

Copyright for this article is retained by the author(s), with first publication rights granted to the journal.

This is an open-access article distributed under the terms and conditions of the Creative Commons Attribution license (http://creativecommons.org/licenses/by/3.0/). 